\title{
Health care of sexual and gender minorities: an integrative literature review
}

\author{
Assistência à saúde de minorias sexuais e de gênero: revisão integrativa da literatura
}

Prestación de atención de salud de las minorías sexuales y de género: revisión integrativa de la literatura

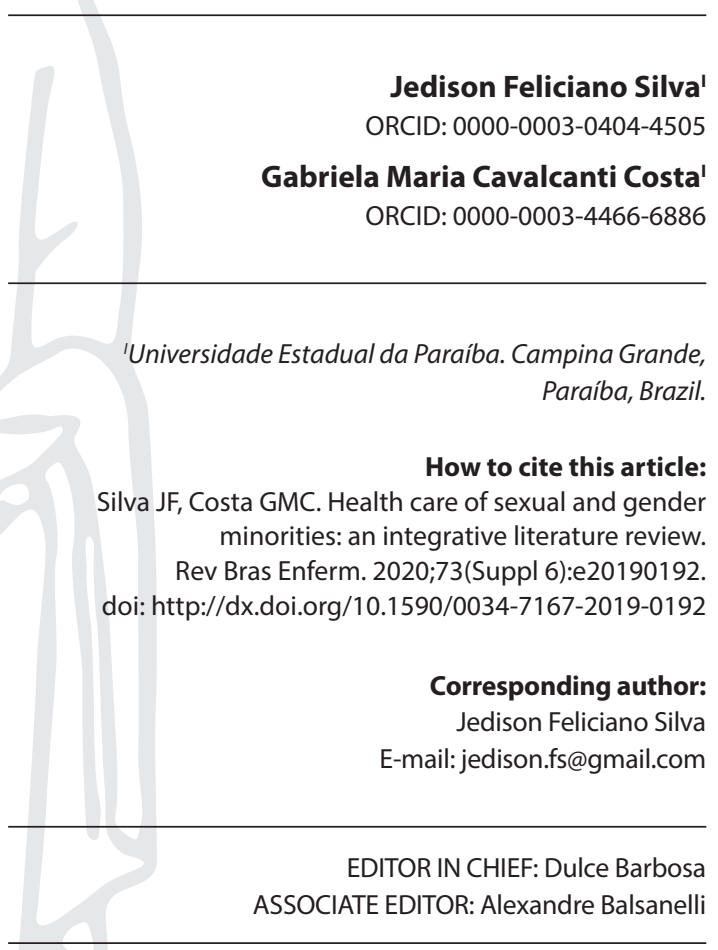

Submission: 03-14-2019
Approval: 05-10-2020

\section{ABSTRACT}

Objectives: to describe health care practices aimed at lesbians, gays, bisexuals, transvestites, and transsexuals. Methods: an integrative literature review based on systematic steps, in MEDLINE, LILACS AND SciELO databases and/or electronic libraries. It was held from September to November 2018, with articles published between 2012 and 2017, available in full in Portuguese, English, and Spanish, addressing health care to that population group. Results: fourteen articles were included. Most of the articles were about the trajectory of individuals within health services and showed limitations and obstacles in the use of these services. Final Considerations: there is evidence that factors related to organization of services, attitude of professionals, stigma, and discrimination experienced undermine health care practices. Therefore, it is essential to carry out educational activities in health services and educational institutions.

Descriptors: Sexual and Gender Minorities; Transgender Persons; Delivery of Health Care; Health Services; Review.

\section{RESUMO}

Objetivos: descrever as práticas assistenciais de atenção à saúde direcionadas a lésbicas, gays, bissexuais, travestis e transexuais. Métodos: revisão integrativa da literatura, baseada em etapas sistemáticas, nas bases de dados e/ou bibliotecas eletrônicas MEDLINE, LILACS E SciELO, no período de setembro a novembro de 2018, com artigos publicados entre 2012 e 2017 disponíveis na íntegra nos idiomas português, inglês e espanhol abordando a assistência à saúde ao referido grupo populacional. Resultados: foram incluídos 14 artigos. A maioria dos artigos versava sobre a trajetória dos indivíduos no interior dos serviços de saúde, evidenciando limitações e obstáculos na utilização destes. Considerações Finais: há evidências de que fatores relacionados à organização dos serviços, postura de profissionais, estigma e discriminação vivenciados comprometem as práticas de assistência à saúde, sendo imprescindível a realização de atividades educativas nos serviços de saúde e instituições de ensino.

Descritores: Minorias Sexuais e de Gênero; Pessoas Transgênero; Assistência à Saúde; Serviços de Saúde; Revisão.

\section{RESUMEN}

Objetivos: describir las prácticas asistenciales de atención a la salud dirigidas a lesbianas, gays bisexuales, travestis y transexuales. Métodos: revisión integrativa, basada en medidas sistemáticas en bases de datos y/o bibliotecas electrónicas MEDLINE, LILACS y SciELO, en el periodo de septiembre a noviembre 2018, con artículos publicados entre 2012 y 2017 disponibles en portugués, inglés, español abordando la asistencia a la salud al referido grupo poblacional. Resultados: se seleccionaron 14 artículos. La mayoría de los artículos versaban sobre la trayectoria de los individuos en el interior de los servicios de salud y evidenciaron limitaciones y obstáculos en la utilización. Consideraciones Finales: hay evidencias de que factores relacionados a la organización de los servicios, a la postura de profesionales, al estigma y la discriminación vivenciados comprometen las prácticas de asistencia a la salud, siendo imprescindible la realización de actividades educativas en los servicios de salud e instituciones de enseñanza.

Descriptores: Minorías Sexuales y de Género; Personas Transgénero; Prestación de Atención de Salud; Servicios de Salud; Revisión. 


\section{INTRODUCTION}

The scientific literature has documented significant differences in the prevalence of diseases and risk factors for lesbian, gay, bisexual, transvestite, and transsexual (LGBT) individuals when compared to their heterosexual peers ${ }^{(1)}$. Historically, individuals who experience practices that differ from the heterosexual norm with different expressions of sexual orientation (that is, desire, affective attraction to the same sex or both) and gender identity (incongruity between the sex attributed at birth and the intrinsic perception of a person being male or female) ${ }^{(2)}$ have been positioned in a place of restricted rights, being exposed to recurring marginalizing experiences, which have a negative impact on their health status ${ }^{(3)}$.

In this perspective, population-based studies have identified complex health indicators within subpopulations that make up the LGBT community, such as concentration of HIV/AIDS among transsexuals and men who have sex with other men ${ }^{(4)}$; alarming global rates of mental disorders and suicide attempts among young people and LGBT adults ${ }^{(5)}$; greater propensity to use alcohol and psychoactive substances ${ }^{(6)}$; and lesbian and bisexual women most likely to develop obesity and cardiovascular disease $\mathrm{e}^{(7)}$.

Such health inequalities are often associated with the social contexts in which these individuals are inserted and the stigmatizing and discriminatory processes to which they are subjected. Vencato ${ }^{(8)}$ suggests that "we tend to interpret what we do not know (recognize) as belonging to the order of the strange, the weird, the inappropriate, the wrong, and that can and should be excluded, removed or even eliminated".

This conception, guided by a gender normalizing perspective, has relegated different sexual orientations and gender identities to a place of unintelligibility ${ }^{(2)}$. It reproduced experiences of victimization and social exclusion that compromise the use of health services by the LGBT community. Studies that point out that accessibility of these groups to health is permeated by a series of inequities, violations, and obstacles are common ${ }^{(9)}$.

In view of the above, it is imperative to understand how sexual and gender minorities transit health services.

\section{OBJECTIVES}

To describe, through evidence available in the literature, health care assistance practices directed at lesbians, gays, bisexuals, transvestites, and transsexuals.

\section{METHODS}

This is an integrative literature review. This method aims to gather and synthesize research results on a specific topic or issue, in a systematic and orderly manner, contributing to the deepening of the knowledge of the investigated topic. Such method is organized into six stages: 1) identification of the theme and selection of the hypothesis or research question; (2) establishment of criteria for inclusion and exclusion of studies; (3) definition of the information to be extracted from the selected studies; (4) assessment of the included studies; (5) interpretation of results; and (6) presentation of the review ${ }^{(10)}$.
At first, the study question was identified: what are the health care assistance practices aimed at lesbians, gays, bisexuals, transvestites, and transsexuals? Then, the keywords "Sexual and Gender Minorities", "Transgender People", "Health Care”, and "Health Services" were defined from the vocabulary of Health Sciences Descriptors (DeCS), as it is a terminology common to research. They were then combined together using the Boolean operator AND (sexual and gender minorities AND health care; sexual and gender minorities AND health services; transgender people AND health care; transgender people AND health services), in the following databases and/or electronic libraries: Medical Literature Analysis and Retrieval System Online (MEDLINE), Latin American \& Caribbean Literature in Health Sciences (LILACS), and Scientific Electronic Library Online (SciELO). The same search strategy was carried out in all databases and/or electronic libraries.

The inclusion criteria for the articles for analysis were: addressing the LGBT population, published between 2012 and 2017, available in full, in Portuguese, English and Spanish, dealing with care practices directed at these population groups. Theses, dissertations, opinion articles, editorials, other reviews, duplicate articles and publications that did not address this topic were excluded. The collection period took place from September to November 2018.

For data analysis, an analytical framework was built, which made it possible to gather and synthesize key information from studies. The collection instrument gathered the following information: title, author(s)/year of publication/country, objective, method, main results regarding health care practices and Level of evidence, according to the classification proposed by Joanna Briggs Institute (JBI).

$\mathrm{JBI}$ recommends classification of studies in a pyramid form and the base is level 5 (expert opinion); then, level 4 has descriptive observational studies; level 3 has analytical observational studies; level 2 has quasi-experimental studies; and level 1 has experimental studies. There are also subdivisions using letters in each level. For instance, at level 1 there is: 1 a, systematic reviews (SR) of randomized controlled trials (RCT); $1 \mathrm{~b}$, SR of RCT and other drawings; 1c, RCT; and 1d, pseudo RCTs ${ }^{(11)}$.

This protocol of this review is registered at PROSPERO platform (https://www.crd.york.ac.uk/PROSPERO), under number CRD42019114633.

\section{RESULTS}

At first, a total of 628 studies were identified in the referred databases, as illustrated in Figure 1, which followed the PRISMA recommendations ${ }^{(12)}$ to describe the literature search process. One hundred eighty-five duplicate articles were excluded, leaving 443 unique articles. Then, the titles and abstracts were read, observing the inclusion and exclusion criteria. As a result of this process, 118 articles were excluded and another 325 articles met the eligibility criteria. Then, two reviewers started full and in-depth reading of these studies, independently. Any disagreements among the evaluators, which arose during this stage, were worked out and resolved by striking a happy medium, which resulted in a final sample of 14 articles. 


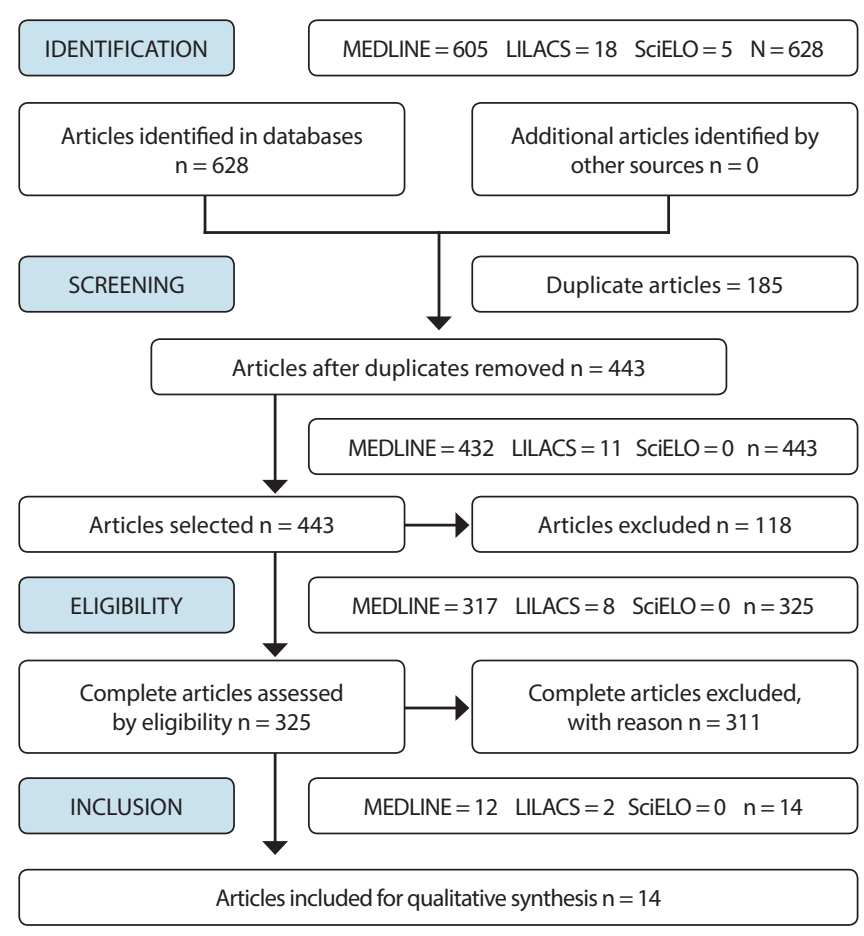

Figure 1 - PRISMA flowchart of the search and selection stages of the analyzed articles
The articles included in this synthesis (Chart 1) were developed in six different countries: Brazil $(n=4)$, Canada $(n=4)$, the United States $(n=3)$, South Africa $(n=1)$, Turkey $(n=1)$, and Ireland $(n$ $=1$ ). They covered, in their entirety, as subjects, all individuals belonging to different sexual orientations (gay, lesbian, bisexual) and gender identities (transvestites and transsexuals).

Concerning method, most researchers used a qualitative approach $(n=7)$ to describe and analyze, in depth, the different dimensions in which insertion of LGBT individuals in health services occurs. Another six studies were cross-sectional surveys and in only one of the studies did the authors indicate the use of quantitative and qualitative methods, complementarily. Although this type of methodological design has been shown to be the most appropriate to unveil the varied facets of sexuality and human and social relations, this fact characterizes the totality of articles as being of low level of evidence.

\section{DISCUSSION}

The identified studies revealed the main implications involving health care assistance practices directed at the groups that make up the so-called sexual and gender minorities. An example is an American cross-sectional study carried out by Lacombe-Duncan and Logie $^{(20)}$, which, when comparing breast cancer screening

Chart 1 - Categorization of scientific production included in the review, Campina Grande, Paraíba, Brazil, 2019

\begin{tabular}{|c|c|c|c|c|c|}
\hline TITLE & $\begin{array}{l}\text { AUTHOR(S) } \\
\text { YEAR } \\
\text { COUNTRY }\end{array}$ & OBJECTIVE & METHOD & RESULTS & $\begin{array}{l}\text { LEVEL OF } \\
\text { EVIDENCE }\end{array}$ \\
\hline $\begin{array}{l}\text { A Política Nacional } \\
\text { de Saúde Integral de } \\
\text { Lésbicas, Gays, Bissexuais } \\
\text { e Transgêneros (LGBT) } \\
\text { eo acesso ao Processo } \\
\text { Transexualizador no } \\
\text { Sistema Único de Saúde } \\
\text { (SUS): avanços e desafios' }\end{array}$ & $\begin{array}{l}\text { Popadiuk GS, } \\
\text { Oliveira DC, } \\
\text { Signorelli MC. } \\
\text { Brazil/2017 }\end{array}$ & $\begin{array}{l}\text { To analyze how the } \\
\text { Transsexualizing Process } \\
\text { has been implemented. }\end{array}$ & $\begin{array}{l}\text { Descriptive } \\
\text { Mixed } \\
\text { Methods }\end{array}$ & $\begin{array}{l}\text { It is observed that from } 2008 \text { onwards, the } \\
\text { transsexual population started to receive } \\
\text { care based on their specificities through } \\
\text { ambulatories and hospitals qualified for the } \\
\text { Transsexualizing Process. The quantitative } \\
\text { data showed that there is a constancy in } \\
\text { performing sexual reassignment surgeries, } \\
\text { even though there is a need to expand } \\
\text { access to this service. }\end{array}$ & LoE 4b \\
\hline $\begin{array}{l}\text { Addressing Health Care } \\
\text { Disparities Among } \\
\text { Sexual } \\
\text { Minorities }^{(14)}\end{array}$ & $\begin{array}{l}\text { Baptiste-Roberts } \\
\text { K, Oranuba } \\
\text { E, Werts N, } \\
\text { Edwards LV. } \\
\text { The United } \\
\text { States/2017 }\end{array}$ & $\begin{array}{l}\text { To discuss health } \\
\text { disparities among women } \\
\text { of sexual minorities } \\
\text { (lesbians, bisexual women, } \\
\text { women who have sex with } \\
\text { women). }\end{array}$ & $\begin{array}{l}\text { Descriptive } \\
\text { Qualitative }\end{array}$ & $\begin{array}{l}\text { Sexual minority women are more likely to } \\
\text { report poorer physical and mental health } \\
\text { and less access to health services. }\end{array}$ & LoE 4b \\
\hline $\begin{array}{l}\text { LGBT Identity, Untreated } \\
\text { Depression, and Unmet } \\
\text { Need for Mental Health } \\
\text { Services by Sexual } \\
\text { Minority Women } \\
\text { and Trans-Identified } \\
\text { People }{ }^{(15)}\end{array}$ & $\begin{array}{l}\text { Steele LS, Daley } \\
\text { A, Curling D, } \\
\text { Gibson MF, } \\
\text { Green DC, } \\
\text { Williams CC, } \\
\text { Ross LE. } \\
\text { Canada/2017 }\end{array}$ & $\begin{array}{l}\text { To compare unmet } \\
\text { mental health needs and } \\
\text { untreated depression } \\
\text { across four groups: } \\
\text { heterosexual women, } \\
\text { lesbians, bisexual women } \\
\text { and transgender people. }\end{array}$ & $\begin{array}{l}\text { Descriptive } \\
\text { Cross- } \\
\text { sectional }\end{array}$ & $\begin{array}{l}\text { Higher rates of unmet mental health needs } \\
\text { and untreated depression were identified } \\
\text { in trans and bisexual participants partly } \\
\text { explained by differences in social factors, } \\
\text { including experiences of discrimination, } \\
\text { lower levels of social support and systemic } \\
\text { exclusion from health services. }\end{array}$ & LoE 4b \\
\hline $\begin{array}{l}\text { A grounded theory of } \\
\text { bisexual individuals' } \\
\text { experiences of help } \\
\text { seeking }^{(16)}\end{array}$ & $\begin{array}{l}\text { MacKay J, } \\
\text { Robinson M, } \\
\text { Pinder S, } \\
\text { Ross LE. } \\
\text { Canada/2017 }\end{array}$ & $\begin{array}{l}\text { To examine the demand } \\
\text { for mental health services } \\
\text { among bisexuals. }\end{array}$ & $\begin{array}{l}\text { Descriptive } \\
\text { Qualitative }\end{array}$ & $\begin{array}{l}\text { The participants' narratives described mental } \\
\text { health services as discriminatory, medicalizing, } \\
\text { characterized by poor relationship with } \\
\text { providers and being useless. Negative } \\
\text { experiences led to greater stress and participants } \\
\text { generally discontinued using the service. }\end{array}$ & LoE 4b \\
\hline $\begin{array}{l}\text { Health care availability, } \\
\text { quality, and unmet } \\
\text { need: a comparison } \\
\text { of transgender and } \\
\text { cisgender residents of } \\
\text { Ontario, Canada }{ }^{(17)}\end{array}$ & $\begin{array}{l}\text { Giblon R, Bauer } \\
\text { GR } \\
\text { Canada/2017 }\end{array}$ & $\begin{array}{l}\text { To measure health } \\
\text { inequities by comparing } \\
\text { health care between } \\
\text { transgender individuals } \\
\text { and their cisgender peers. }\end{array}$ & $\begin{array}{l}\text { Descriptive } \\
\text { Cross- } \\
\text { sectional }\end{array}$ & $\begin{array}{l}\text { Unmet health needs are identified among } \\
\text { transgender individuals when compared to } \\
\text { their cisgender peers. }\end{array}$ & LoE 4b \\
\hline
\end{tabular}




\begin{tabular}{|c|c|c|c|c|c|}
\hline TITLE & $\begin{array}{l}\text { AUTHOR(S) } \\
\text { YEAR } \\
\text { COUNTRY }\end{array}$ & OBJECTIVE & METHOD & RESULTS & $\begin{array}{l}\text { LEVEL OF } \\
\text { EVIDENCE }\end{array}$ \\
\hline $\begin{array}{l}\text { Exploring Perceived } \\
\text { Discrimination Among } \\
\text { LGBT } \\
\text { Individuals in Turkey in } \\
\text { Education, Employment, } \\
\text { and Health Care: Results } \\
\text { of an Online Survey }\end{array}$ & $\begin{array}{l}\text { Göçmen I, } \\
\text { Yılmaz V. } \\
\text { Turkey/2017 }\end{array}$ & $\begin{array}{l}\text { To measure the perceived } \\
\text { discrimination that } \\
\text { lesbians, gays, bisexuals } \\
\text { and transsexuals report } \\
\text { in education, income, } \\
\text { employment, and health } \\
\text { care. }\end{array}$ & $\begin{array}{l}\text { Descriptive } \\
\text { Cross- } \\
\text { sectional }\end{array}$ & $\begin{array}{l}\text { LGBT individuals report experiencing } \\
\text { discrimination in access to education, } \\
\text { employment and health care. }\end{array}$ & $\operatorname{LoE} 4 \mathrm{~b}$ \\
\hline $\begin{array}{l}\text { Barriers to Health } \\
\text { Care Among Adults } \\
\text { Identifying as Sexual } \\
\text { Minorities: A US National } \\
\text { Study }^{(19)}\end{array}$ & $\begin{array}{l}\text { Dahlhamer JM, } \\
\text { Galinsky AM, } \\
\text { Joestl SS, } \\
\text { Ward BW. } \\
\text { The United } \\
\text { States/2016 }\end{array}$ & $\begin{array}{l}\text { To assess the extent to } \\
\text { which lesbian, gay and } \\
\text { bisexual adults ( } 18 \text { to } 64 \\
\text { years old) face barriers to } \\
\text { health care. }\end{array}$ & $\begin{array}{l}\text { Descriptive } \\
\text { Cross- } \\
\text { sectional }\end{array}$ & $\begin{array}{l}\text { Members of the sexual minorities studied } \\
\text { may be delayed or stopped receiving health } \\
\text { care due to concerns or fears about disclosing } \\
\text { their sexual orientation, lack of adequate } \\
\text { prevention services, or absence of providers } \\
\text { versed in the needs of these groups. }\end{array}$ & $\operatorname{LoE} 4 b$ \\
\hline $\begin{array}{l}\text { Correlates of clinical breast } \\
\text { examination among } \\
\text { lesbian, gay, bisexual, and } \\
\text { queer women }\end{array}$ & $\begin{array}{l}\text { Lacombe- } \\
\text { Duncan A, } \\
\text { Logie } \mathrm{CH} \text {. } \\
\text { Canada/2016 }\end{array}$ & $\begin{array}{l}\text { To analyze compliance } \\
\text { with breast cancer } \\
\text { screening among women } \\
\text { of sexual minorities. }\end{array}$ & $\begin{array}{l}\text { Descriptive } \\
\text { Cross- } \\
\text { sectional }\end{array}$ & $\begin{array}{l}\text { Perception of stigma and belief that the } \\
\text { caregiver is uncomfortable with the patient's } \\
\text { sexual orientation were identified as responsible } \\
\text { for a lower demand for screening services. }\end{array}$ & LoE 4b \\
\hline $\begin{array}{l}\text { Saúde de Minorias } \\
\text { Sexuais do } \\
\text { Nordeste Brazileiro: } \\
\text { Representações, } \\
\text { Comportamentose } \\
\text { Obstáculos } \\
\text { (21) }\end{array}$ & $\begin{array}{l}\text { Garcia } C L \text {, } \\
\text { Albuquerque, } \\
\text { GA, Drezett J, } \\
\text { Adami, F } \\
\text { Brazil/2016 }\end{array}$ & $\begin{array}{l}\text { To analyze Social } \\
\text { Representations about } \\
\text { health and the main } \\
\text { iniquities, deadlocks, and } \\
\text { challenges experienced by } \\
\text { this minority group when } \\
\text { accessing health services. }\end{array}$ & $\begin{array}{l}\text { Descriptive } \\
\text { Qualitative }\end{array}$ & $\begin{array}{l}\text { The study population presented reductionist } \\
\text { representations of health, sought health } \\
\text { services from a healing perspective and } \\
\text { faced challenges/obstacles in accessing } \\
\text { health services. }\end{array}$ & LoE 4b \\
\hline $\begin{array}{l}\text { Dificuldades vividas por } \\
\text { pessoas trans no acesso } \\
\text { ao Sistema Único de } \\
\text { Saúde }\end{array}$ & $\begin{array}{l}\text { Rocon PC, } \\
\text { Rodrigues A } \\
\text { Zamboni J, } \\
\text { Pedrini MD. } \\
\text { Brazil/2016 }\end{array}$ & $\begin{array}{l}\text { To discuss the difficulties } \\
\text { of transgender people } \\
\text { in the metropolitan } \\
\text { region of Grande Vitória, } \\
\text { state of Espírito Santo, in } \\
\text { accessing health services. }\end{array}$ & $\begin{array}{l}\text { Descriptive } \\
\text { Qualitative }\end{array}$ & $\begin{array}{l}\text { The results pointed out disrespect to the } \\
\text { social name, discrimination and diagnosis } \\
\text { in the Transsexualizing Process as main } \\
\text { limitations in access to the health system. }\end{array}$ & LoE 4b \\
\hline $\begin{array}{l}\text { Experiences of } \\
\text { homosexual patients' } \\
\text { access to primary health } \\
\text { care services in Umlazi, } \\
\text { KwaZulu-Natal(23) }\end{array}$ & $\begin{array}{l}\text { Cele NH, } \\
\text { Sibiya MN, } \\
\text { Sokhela DG. } \\
\text { South } \\
\text { Africa/2015 }\end{array}$ & $\begin{array}{l}\text { To describe the } \\
\text { experiences of } \\
\text { homosexual patients } \\
\text { who use primary health } \\
\text { care services. }\end{array}$ & $\begin{array}{l}\text { Descriptive } \\
\text { Qualitative }\end{array}$ & $\begin{array}{l}\text { Participants cited experiences of prejudice } \\
\text { and stigmatization as the main reasons for } \\
\text { not receiving adequate treatment from } \\
\text { health care providers after gaining access to } \\
\text { these services. Discrimination was noted by } \\
\text { the participants when they received different } \\
\text { treatment from heterosexuals. }\end{array}$ & LoE 4b \\
\hline $\begin{array}{l}\text { Navigating the System: } \\
\text { How Transgender } \\
\text { Individuals Engage in } \\
\text { Health Care Services }^{(24)}\end{array}$ & $\begin{array}{l}\text { Roller, CG, } \\
\text { Sedlak C, } \\
\text { Draucker, CB. } \\
\text { The United } \\
\text { States/2015 }\end{array}$ & $\begin{array}{l}\text { To describe the process } \\
\text { by which transgender } \\
\text { individuals engage in } \\
\text { health care. }\end{array}$ & $\begin{array}{l}\text { Descriptive } \\
\text { Qualitative }\end{array}$ & $\begin{array}{l}\text { Participants report "challenging and } \\
\text { frustrating" trajectories in health services. }\end{array}$ & LoE 4b \\
\hline $\begin{array}{l}\text { Cuidado com saúde: as } \\
\text { travestis de Santa Maria, } \\
\text { Rio Grande do Sul }\end{array}$ & $\begin{array}{l}\text { Souza, MHT; } \\
\text { Pereira, PPG. } \\
\text { Brazil/2015 }\end{array}$ & $\begin{array}{l}\text { To present the health care } \\
\text { of transvestites in the city } \\
\text { of Santa Maria, state of } \\
\text { Rio Grande do Sul, Brazil. }\end{array}$ & $\begin{array}{l}\text { Descriptive } \\
\text { Qualitative }\end{array}$ & $\begin{array}{l}\text { In the rare situations in which they } \\
\text { sought health services, they did not meet } \\
\text { expectations or respond to users' demands. }\end{array}$ & LoE 4b \\
\hline $\begin{array}{l}\text { Survey of lesbian, } \\
\text { gay, bisexual, and } \\
\text { transgender } \\
\text { people's experiences of } \\
\text { mental health services } \\
\text { in Ireland } \\
\text { (26) }\end{array}$ & $\begin{array}{l}\text { McCann E, } \\
\text { Sharek D. } \\
\text { Ireland/2014. }\end{array}$ & $\begin{array}{l}\text { To explore the } \\
\text { experiences and needs of } \\
\text { LGBT subjects in relation } \\
\text { to mental health services. }\end{array}$ & $\begin{array}{l}\text { Descriptive } \\
\text { Cross- } \\
\text { sectional }\end{array}$ & $\begin{array}{l}\text { Two-thirds of respondents felt that mental } \\
\text { health services were unable to respond to } \\
\text { health needs, while one-third felt they could } \\
\text { not speak to their health care provider about } \\
\text { LGBT issues. Most respondents felt that the } \\
\text { team assumed they were heterosexual. }\end{array}$ & LoE 4b \\
\hline
\end{tabular}

Note: LGBT - Lesbians, Gays, Bisexuals, Transvestites and Transsexuals.

among lesbian and/or bisexual women with sexual orientation and their heterosexual peers, pointed out less compliance with preventive exams and looking for this type of service among the first ones, due to their perception of stigma or discrimination. The authors show that, although they are more likely to develop breast cancer, due to biological and behavioral risk factors, such as higher rates of nulliparity and alcoholism, women of non-heterosexual orientation, anticipating the negative impact that their sexuality may have on the quality of services provided, end up delaying or even failing to access health institutions.
Actual or presumed stigma and discrimination are also related to underutilization of preventive cervical cancer screening services $^{(20,27)}$. As Baptiste-Roberts et al. ${ }^{(14)}$ point out, when discussing health disparities that affect lesbian and bisexual women, low compliance with screening tests (clinical breast examination, mammography, and oncotic colpocytology) may be related to the stressful social environment to which women from stigmatized social groups are exposed. As a result of inadequate engagement with screening services, homosexual women tend to detect these types of cancers later. 
The authors of this study also problematize other dimensions that affect health care assistance practices directed at lesbian and bisexual women, such as the presumption that they are inherently low risk groups for sexually transmitted infection transmission due to their sexual dynamics. This misperception, explicitly promoted by some medical science professionals and self-perpetuating within the lesbian community, becomes a problematic issue, as the transmission, from woman to woman, of several sexually transmitted infections (including HIV, syphilis and herpes) genital) is possible and widely documented in the literature ${ }^{(14)}$.

The flagrant ignorance related to particularities of care for homosexual women often shows how much health care practices can be fragmented and decontextualized. Previous research carried out in Brazil already denounced the difficulties faced by these social actresses, which were expressed by discomfort and embarrassment typical of gynecological examination; lack of lesbian specificity in health services; and unpreparedness of professionals regarding the health needs of homosexual women ${ }^{(28)}$.

Baptiste-Roberts et al. ${ }^{(14)}$ reinforce that it is in this delicate context that lesbian and bisexual women may hesitate to disclose, or even not to disclose, their sexual orientation to a caregiver. Fear related to the possibility of discrimination, which contributes to invisibility perpetuation of homosexual identities, ends up compromising assistance and reinforcing heterosexist behaviors, especially by health professionals.

This is a similar point of view perceived in the findings of Cele, Sibiya, and Sokdela ${ }^{(23)}$. When investigating how homosexual individuals move through South Africa's Primary Health Care services, they identified reports of dissatisfaction and institutional rejection. Participants (gays and lesbians) described experiences of prejudice and stigmatization as the main reasons for not accessing health facilities or receiving adequate care. Discrimination attributed to the differential treatment they received based on their sexual orientation, after identifying themselves as homosexuals, was one of the most sensitive points.

The verbalized speeches show moments when participants' sexuality seemed to disturb caregivers. The inability of most health professionals to manage issues related to sexual orientations and/ or gender identities was revealed. The aforementioned, in turn, directly contributes to assuming negative attitudes or attitudes that discourage users from using these services ${ }^{(23)}$.

Health professional unpreparedness to deal with sexual and gender diversity is one of the most scored sub-themes in the analyzed academic production. Mackay et al.(16), in their study involving bisexual individuals, expose narratives in which participants stated to discontinue assistance follow-up when they considered their caregiver lacking relevant knowledge on issues related to their sexual orientation; their needs have not been met; care was perceived as inadequate and/or suffered prejudice. This finding is also present in the considerations of Dahlhamer et al. ${ }^{(19)}$. They claim that members belonging to sexual and gender minority groups are more exposed to lack of adequate assistance services and culturally competent providers versed in the needs inherent to these subjects.

The problematic interaction between health professionals and subpopulation members that make up the LGBT community is intrinsically related to the limited way in which these individuals use health spaces. A survey by Göçmen and Yilmaz ${ }^{(18)}$, with 2,875 respondents, revealed that $8 \%$ of them reported abstaining from accessing health services due to fear of facing prejudices based on their gender identity and/or sexual orientation. Among those who entered health services, $53 \%$ preferred not to identify themselves as gay, lesbian, bisexual or transsexual and another $14 \%$ stated that they had suffered discrimination.

Contexts like this confirm the feeling of dissatisfaction that drives most LGBT users out of health services. In their analysis of the inequities that affect this public, Garcia et al. ${ }^{(21)}$ point out difficulties regarding professional performance, their lack of preparation and the existence of discrimination and institutional prejudice as challenging points for access to health.

The authors of this study suggest the existence of a vicious circle, based on the speeches of the researched subjects. On one hand, users are not aware of the importance of health-promoting services, and therefore do not seek it; on the other, professionals do not have the necessary qualification and awareness about LGBT health to attract the population to health spaces. Moreover, they add that the flagrant deficiency in embracing these groups, added to program inadequacy and to professional approach augmented by mistaken and stereotyped perceptions, ends up being reflected in difficulty of access, in assistance disqualification and foreseeable distancing from care actions and health promotion $^{(21)}$.

With a view to breaking this cycle, scholars note that the need to raise awareness of non-discriminatory care remains one of the most recurring themes in plans, programs and other documents that present guidelines, objectives and goals for public health policies formulated for these communities ${ }^{(29)}$. It is perceived as fundamental that health professional training is not only technical, but also crossed by the understanding of the human and the social ${ }^{(30)}$, and that qualification and awareness in serving this population are fundamental to include these subjects ${ }^{(31)}$. The Association of American Medical Colleges (AAMC), in order to achieve this goal, recommends that the curricula of medical schools and health sciences should guarantee to their students' mastery of skills, attitudes, and necessary knowledge about issues involving sexual orientation and gender identity. By informing and sensitizing the subjects in the course of their training period, it is intended to deconstruct prejudices and unknowns responsible for inadequate and discriminatory care, as well as to reduce the negative effect of health professional and service unpreparedness to deal with the different expressions of sexuality and gender, ensuring a more comprehensive understanding of the specific needs of each individual(32).

Still with regard to minority sexual and gender groups, some seem to face greater challenges, such as transvestites and transsexuals. Mello et al. ${ }^{(29)}$ assert that, among the LGBT population as a whole, they seem to be the groups that most intensely feel the scarcity of specific health policies. Not only for claiming specialized care for demands that are not placed on other population segments (bodily changes associated with the use of hormones and silicone, for example), but also due to the intensity of the social stigma that usually affects these identity groups, especially when they are also discriminated against from other 
social markers such as income and education levels, race/color and physical appearance. A research carried out by Sousa and Pereira ${ }^{(25)}$ highlights that meeting the demand of these populations, with difficulties aggravated by social problems, has been a major challenge for public health.

This perspective is shared in a study by Roller, Sedlak and Draucker ${ }^{(24)}$. When investigating how transsexual individuals "navigate" in health services, they bring reports from individuals who described a "challenging and frustrating" trajectory requiring "persistence, diligence and courage". As stated by Souza and Pereira ${ }^{(25)}$, "they perceive, from the first attempt, a barrier in the service, which already begins with their identification". The authors reinforce that in the rare situations in which they sought health services, expectations and demands of users were unmet and were considered inadequate by them. The same conclusion was present in the survey conducted by Giblon and Bauer ${ }^{(17)}$, which identified poor quality of services and health needs not carried out among Canadian transsexual men and women.

Other publications ${ }^{(22,30)}$ also expose numerous difficulties in the use and permanence of transsexual people in health services, highlighting aspects such as disrespect to the social name and trans/trans-transphobia. These cited as some of the obstacles to seeking and obtaining services and the cause of treatment abandonment (even in the case of serious and chronic diseases such as AIDS).

Within the transsexual universe, there is still the current that discusses the (de) pathologization of transvestite and transsexual gender identities in the health-disease process. Transsexuality is seen by the World Health Organization (WHO) as a type of gender identity disorder, in which individuals identify themselves with a masculinity and/or femininity different from that expected by society due to their biological sex ${ }^{(13)}$. Thus, the definition of transsexuality ends up characterizing transsexual subjects as beings with a pathology and an International Classification of Diseases (ICD), which identifies them ${ }^{(33)}$.

When problematizing the psychiatric diagnosis embedded within the construction process of transsexual bodies, Rocon et al. ${ }^{(22)}$ expose the coexistence of divergent points of view. Some defend maintaining the diagnosis, treating the pathologization of transsexual identities as a political strategy to guarantee maintenance of public health services; others point to the diagnosis as causing marginalization and exclusion of these same services.

For the authors, the diagnoses have operated as a promoter of selectivity limiting the access of transsexual individuals to health services. They are based on stereotypes of masculinity and femininity referenced in the binary gender and heteronormativity. They state that it is necessary to point out that the possible suffering experienced by transvestites and transsexuals is not due to any pathology inherent to such subjects, but as a consequence of trajectories of exclusion ${ }^{(22,34)}$.

Other authors who defend the non-pathologization of transvestite and transsexual gender identities argue that the discriminatory effect of psychiatric diagnosis of a sexual condition, considered necessary to access available medical resources, merits further study. It appears that exercising transsexual patient autonomy is more limited than that usually accepted for other therapeutic processes. Such limitations bring challenges and difficulties for health professionals and negative effects on the health of people who modify their bodies. Autonomy restriction of subjects in this context has, as a consequence, exclusion, in the official health system, of patients who do not fulfill the diagnostic criteria for access to body changes. This implies that excluded people make such changes themselves or look for them in clandestine services. Such services, due to their precariousness, can offer risk and, above all, raise the standards of vulnerability to which these groups are exposed ${ }^{(22,25,35-36)}$.

In this sense, it is emphasized that in transsexuality, the importance of health services consists not only in care of the healthdisease process, but fundamentally in a self-building strategy. Image and appearance are attributes of great importance in contemporary societies. Many cisgender people (who do not report incongruity between their bodies and the gender assigned at birth), countless transsexual people invest in shaping their bodies as a constituent element of their lives. What varies are the body transformation procedures that, for transsexual people, may consist of investments such as hormone therapy, silicone applications, mastectomy, plastic surgery or transgenitalization ${ }^{(22)}$.

Although it is correct to say that not every transsexual individual wishes to undergo such profound bodily changes, Popadiuk, Oliveira and Signorelli ${ }^{(13)}$ show that the results of these procedures can have a positive impact on these people's lives. A study that assessed the result of the surgical procedure and social and psychological adjustments through the monitoring of 136 transsexuals who underwent sexual reassignment showed that $70 \%$ of those who underwent the procedure improved their social, psychological, and psychiatric aspects after surgery.

In Brazil, ten years after the institutionalization of SUS (Sistema Único de Saúde - Brazilian health system) Transsexualizing Process, Popadiuk, Oliveira and Signorelli ${ }^{(13)}$ noted that the initiative to aggregate and meet the demands of such social actors and actresses has not yet been universalized by all states and regions from the country. Only in Porto Alegre, state of Rio Grande do Sul, Rio de Janeiro, state of Rio de Janeiro, Goiânia, state of Goiás, São Paulo, state of São Paulo and Recife, state of Pernambuco there are centers qualified for sexual reassignment surgery. Such centers are complemented by an outpatient care network in Uberlândia, state of Minas Gerais, Curitiba, state of Paraná, João Pessoa, state of Paraíba, Belém, state of Pará and São Paulo, state of São Paulo, which represents a certain limitation in access to these services ${ }^{(22)}$.

In addition to these difficulties in obtaining medical resources, there are those related to issues of marital status of persons submitted to bodily transformation processes. Self-attribution of a new name follows the body's transformation processes ${ }^{(22)}$. However, despite specific legislation ${ }^{(37)}$ and consensus that changing the identity of transsexual subjects is a comprehensive and fundamental part of "treatment"(35) and social inclusion, discourses of disrespect to this prerogative are not uncommon ${ }^{(22,25)}$, which still places such an instrument in the field of good ideas and intentions.

Another recurring topic in the academic production raised refers to the insertion of lesbians, gays, bisexuals, transvestites and transsexuals in mental health services. The specialized literature has associated recurrent experiences of stigmatization and discrimination with the profound physiological impact that chronic stressors have on the health of these communities ${ }^{(38)}$. 
In their work, Steele et al. ${ }^{(15)}$ identified higher rates of unmet mental health needs and untreated depression in trans and bisexual participants. Such rates were partly explained by differences in social factors, including experiences of discrimination, lower levels of social support and systemic exclusion from health services. The authors also inferred that despite the recognition of the influence that social determinants have on the health status of individuals, care practices perceived in the analyzed context are still based on a predominant biomedical treatment approach. This same perception can be observed in the study by MacKay et al. ${ }^{(16)}$. They point out that dimensions and singularities of non-cisgender identities and different sexual orientations are undervalued or obliterated. Discourses that reflect experiences in mental health services as mostly negative, discriminatory and medicalizing are common.

Such findings are similar to those found by McCann and Sharek ${ }^{(25)}$ in their study on experiences of homosexual individuals in Irish mental health services. Data from this research point out the participants' concerns about limited access to alternative therapies and abuse of prescribed psychoactive substances. The survey also states that two-thirds of the participants felt that mental health services were unable to respond to their health needs. One third felt that they could not speak to their caregiver about LGBT issues or that they did not have sufficient knowledge about the particularities of these groups. Most respondents also reported that the health team assumed that they were heterosexual, contributing to maintenance of heterosexist attitudes within the services.

In general, it is observed that the LGBT segment still misses more targeted services, proposed by specialized and culturally sensitive individuals who do not reproduce (even if indirectly) normative attitudes and speeches.

\section{Study limitations}

Since this is an integrative review, the results refer only to the portrait of the investigated reality. The fact that all articles fall under a low level of evidence, based on small, nonrandomized samples, makes it clear the little scientific relevance that the data describing health care practices of the LGBT population receives.

\section{Contributions to nursing, health, and public policies}

Discussions about the health of specific population groups are relatively recent and scarce. Although the movements of struggles for equality and equity of rights have come a long way, achievements have not shown evident reflexes in health care practices aimed at lesbians, gays, bisexuals, transvestites and transsexuals. Specificities persist that deserve attention in the social and care spheres, verified from existence of factors that characterize difficulty access and reception of these groups when looking for preventive actions and health care. The evidence and information identified in this review ratify deficiencies and gaps in academic and professional training, which demand attention and provide subsidies for planning public health policies that meet LGBT population's needs.

\section{FINAL CONSIDERATIONS}

It was possible to incite a reflection on the fragility of health care practices related to sexual and gender minorities from the data collected. Discourses that reflect prejudice and discrimination the LGBT population suffer are numerous and common and the extent to which these negative experiences can directly contribute to precarious health conditions.

Transformations in this scenario permeate changes in beliefs and values that have long permeated social relations and that relegate subjects and populations marked by gender and sexuality variations to a place of unintelligibility. Education of culturally and socially sensitive professionals capable of promoting provision of quality health services are added to the aforementioned. Only by setting a positive agenda of intentions that provides greater access to health actions and services, will it be possible to create conditions that break the chain of prejudices, discrimination and social exclusion that interferes with and prevents the full exercise of LGBT individuals when seeking assistance.

\section{REFERENCES}

1. Corrêa-Ribeiro R, Iglesias F, Camargos FE. What do physicians know about homosexuality? translation and adaptation of knowledge about homosexuality questionnaire. Einstein (São Paulo) [Internet]. 2018 [cited 2019 Jan 15];16(3):1-9. Available from: http://www.scielo.br/pdf/ eins/v16n3/2317-6385-eins-16-03-eA04252.pdf

2. Winter S, Diamond M, Green J, Karasic D, Reed T, Whittle S, Wylie K. Transgender people: health at the margins of Society. Lancet [Internet]. 2016 [cited 2019 Jan 15]; 388(10042):390-400. Available from: https://www.ncbi.nlm.nih.gov/pubmed/27323925

3. Paulino DB, Rasera EF, Teixeira FB. Discourses on the healthcare of lesbian, gay, bisexual, and transgender (LGBT) people adopted by doctors working in Brazil's Family Health Strategy. Interface (Botucatu). 2019;23:e180279. doi: 10.1590/interface.180279

4. Malta M, Magnanini MM, Mello MB, Pascom AR, Linhares Y, Bastos FI. HIV prevalence among female sex workers, drug users and men who have sex with men in Brazil: a systematic review and meta-analysis. BMC Public Health [Internet]. 2010 [cited 2019 Jan 15];10: 317. Available from: https://www.ncbi.nlm.nih.gov/pubmed/20529289

5. Haas AP, Eliason M, Mays VM, Mathy RM, Cochran SD, D'Augelli AR, et al. Suicide and suicide risk in lesbian, gay, bisexual, and transgender populations: review and recommendations. J Homosex [Internet]. 2011[cited 2019 Jan 15];58(1):10-51. Available from: https://www.ncbi. nlm.nih.gov/pubmed/21213174 
6. Goldberg S, Strutz KL, Herring AA, Halpern CT. Risk of substance abuse and dependence among young adult sexual minority groups using a multidimensional measure of sexual orientation. Public Health Rep [Internet]. 2013 [cited 2019 Jan 15];128(3):144-52. Available from: https://www.ncbi.nlm.nih.gov/pubmed/23633729

7. Fredriksen-Goldsen Kl, Kim HJ, Barkan SE, Muraco A, Hoy-Ellis CP. Health disparities among lesbian, gay, and bisexual older adults: results from a population-based study. Am J Public Health [Internet]. 2013 [cited 2019 Jan 15];103(10):1802-9. Available from: https://www.ncbi. nlm.nih.gov/pmc/articles/PMC3770805/

8. Vencato AP. Diferenças na escola. In: Miskolci R, Leite Jr J. Diferenças na educação: outros aprendizados. São Carlos: EdUFSCar; 2014. p. 19-56

9. Lionço T. What do health rights mean for the GLBT population? Considering human, sexual and reproductive rights in the search for equity and integrality in the health system. Saude Soc[Internet]. 2008 [cited 2019 Jan 15];17(2): 11-21. Available from: http://www.scielo.br/pdf/ sausoc/v17n2/03.pdf

10. Mendes KDS, Silveira RCCP, Galvão CM. Revisão integrativa: método de pesquisa para a incorporação de evidências na saúde e na enfermagem. Texto Contexto Enferm [Internet]. 2008 [cited 2019 Jan 15];17(4):758-64. Available from: http://www.scielo.br/pdf/tce/v17n4/18.pdf

11. The Joanna Briggs Institute. New JBI levels of evidence[Internet] 2013 [cited 2019 Jan 15]. Available from: http://joannabriggs.org/ assets/ docs/approach/JBI-Levels-of-evidence_2014.pdf

12. Moher D, Liberati A, Tetzlaff J, Altman DG; PRISMA Group. Preferred reporting items for systematic review sand meta-analyses: the PRISMA statement. Ann Intern Med [Internet]. 2009 [cited 2019 Jan 15];151: 264-9. Available from: http://www.ncbi.nIm.nih. gov/ pubmed/19622511. Available from: http://www.scielo.br/pdf/csc/v22n5/1413-8123-csc-22-05-1509.pdf

13. Popadiuk GS, Oliveira DC, Signorelli MC. The National Policy for Comprehensive Health of Lesbians, Gays, Bisexuals and Transgender (LGBT) and access to the Sex Reassignment Process in the Brazilian Unified Health System (SUS): progress and challenges. Ciênc Saúde Coletiva [Internet]. 2017[cited 2019 Jan 15];22(5):1509-20. Available from: http://www.scielo.br/pdf/csc/v22n5/1413-8123-csc-22-05-1509.pdf

14. Baptiste-Roberts K, Oranuba E, Werts N, Edwards LV. Addressing Health Care Disparities Among Sexual Minorities. Obstet Gynecol Clin North Am [Internet]. 2017 [cited 2019 Jan 15];44(1):71-80. Available from: https://www.ncbi.nlm.nih.gov/pubmed/28160894

15. Steele LS, Daley A, Curling D, Gibson MF, Green DC, Williams CC, Ross LE. LGBT Identity, Untreated Depression, and Unmet Need for Mental Health Services by Sexual Minority Women and Trans-Identified People. J Womens Health (Larchmt)[Internet]. 2017 [cited 2019 Jan 15];26(2):116-127. Available from: https://www.ncbi.nlm.nih.gov/pubmed/27898255

16. MacKay J, Robinson M, Pinder S, Ross LE. A grounded theory of bisexual individuals' experiences of help seeking. Am J Orthopsychiatry [Internet]. 2017 [cited 2019 Jan 15];87(1):52-61. Available from: https://www.ncbi.nlm.nih.gov/pubmed/27148752

17. Giblon R, Bauer GR. Health care availability, quality, and unmet need: a comparison of transgender and cisgender residents of Ontario, Canada. BMC Health Serv Res [Internet]. 2017 [cited 2019 Jan 15];17:283. Available from: https://www.ncbi.nlm.nih.gov/pmc/articles/ PMC5395792/pdf/12913_2017_Article_2226.pdf

18. Göçmen I, YIImaz V. Exploring perceived discrimination among LGBT individuals in Turkey in education, employment, and health care: results of an online survey. J Homosex [Internet]. 2017 [cited 2019 Jan 15];64(8):1052-68. Available from: https://www.ncbi.nlm.nih.gov/ pubmed/27645489

19. Dahlhamer JM, Galinsky AM, Joestl SS, Ward BW. Barriers to Health care among adults identifying as sexual minorities: A US National Study. Am J Public Health [Internet]. 2016 [cited 2019 Jan 15];106(6):1116-22. Available from: https://www.ncbi.nlm.nih.gov/pubmed/26985623

20. Lacombe-Duncan A, Logie CH. Correlates of clinical breast examination among lesbian, gay, bisexual, and queer women. Can J Public Health [Internet]. 2016 [cited 2019 Jan 15];107(4-5):e467-e472. Available from: https://www.ncbi.nlm.nih.gov/pubmed/28026715

21. Garcia CL, Albuquerque GA, Drezett J, Adami, F. Health of sexual minorities in north-eastern Brazil: representations, behaviours and obstacles. J Hum Growth Dev [Internet]. 2016 [cited 2019 Jan 15];26(1):94-100. Available from: http://pepsic.bvsalud.org/pdf/rbcdh/v26n1/14.pdf

22. Rocon PC, Rodrigues A, Zamboni J, Pedrini MD. Difficulties experienced by trans people in accessing the Unified Health System. Ciên Saúde Coletiva [Internet]. 2016 [cited 2019 Jan 15];21(8):2517-26. Available from: http://www.scielo.br/pdf/csc/v21n8/en_1413-8123-csc-21-08-2517.pdf

23. Cele NH, Sibiya MN, Sokhela DG. Experiences of homosexual patients' access to primary health care services in Umlazi, KwaZulu-Natal. Curationis [Internet]. 2015 [cited 2019 Jan 15];38(2):1522. Available from: https://www.ncbi.nlm.nih.gov/pubmed/26842074

24. Roller CG, Sedlak C, Draucker CB. Navigating the System: How Transgender Individuals Engage in Health Care Services. J Nurs Scholarsh[Internet]. 2015 [cited 2019 Jan 15];47(5):417-24. Available from: https://www.ncbi.nlm.nih.gov/pubmed/26243380

25. Souza MHT, Pereira PPG. Health care: the transvestites of Santa Maria, Rio Grande do Sul, Brazil. Texto Contexto Enferm [Internet]. 2015 [cited 2019 Jan 15];24(1):146-53. Available from: http://www.scielo.br/pdf/tce/v24n1/pt_0104-0707-tce-24-01-00146.pdf

26. McCann E, Sharek D. Survey of lesbian, gay, bisexual, and transgender people's experiences of mental health services in Ireland. Int J Ment Health Nurs[Internet]. 2014 [cited 2019 Jan 15];23(2):118-27. Available from: https://www.ncbi.nlm.nih.gov/pubmed/23473079

27. Carvalho PMG, Nóbrega BSM, Rodrigues JL, Almeida RO, Abdalla FTM, Nichiata LYI. Prevention of sexually transmitted diseases by homosexual and bisexual women: a descriptive study. Online Braz J Nurs [Internet]. 2013 [cited 2019 Jan 15];12(4):931-41. Available from: http://www.objnursing.uff.br/index.php/nursing/article/view/4177/18_4177_pt

28. Sousa JC, Mallmann DG, Galindo NNM, Freitas NO, Vasconcelos EMR, Araújo EC. Health promotion of lesbian woman: nursing care. Rev Gaúcha Enferm [Internet]. 2014 [cited 2019 Jan 15];35(4):108-13. Available from: http://www.scielo.br/pdf/rgenf/v35n4/pt_1983-1447rgenf-35-04-00108.pdf 
29. Mello L, Perilo M, Braz CA, Pedrosa C. Health policies for lesbians, gays, bisexuals, transsexuals and travestis in Brazil: the pursuit of universality, integrality and equity. Sexualidad, Salud Soc [Internet]. 2011 [cited 2019 Jan 15];(9):7-28. Available from: http://www.scielo.br/ $\mathrm{pdf} / \mathrm{sess} / \mathrm{n} 9 / 02 . \mathrm{pdf}$

30. Angonese M, Lago MCS. Reproductive health and rights for the population of transvestites and transsexuals: abjection and symbolic sterility. Saúde Soc [Internet]. 2017 [cited 2019 Jan 15];26(1):256-70. Available from: http://www.scielo.br/pdf/sausoc/v26n1/1984-0470sausoc-26-01-00256.pdf

31. Oliveira GS, Nogueira JA, Costa GPO, Silva FV, Almeida AS. Access by lesbians, gays, bisexuals and transvestites/transsexuals to the Basic Family Health Units. Rev Rene[Internet]. 2018 [cited 2019 Jan 15];19:e3295. Available from: http://periodicos.ufc.br/rene/article/view/33109/pdf

32. Daniel H, Butkus R. Lesbian, gay, bisexual, and transgender health disparities: executive summary of a policy position paper from the American college of physicians. Ann Int Med [Internet]. 2015 [cited 2020 Jan 15];163(2):135-48. Available from: https://www.ncbi.nlm.nih.gov/pubmed/25961598/

33. Ministério da Saúde (BR). Transexualidade e Travestilidade na Saúde. Brasília (DF); 2015.

34. Aran M, Murta D, Lionço T. Transsexuality and public health in Brazil. Ciênc Saúde Coletiva [Internet]. 2009 [cited 2019 Jan 15];14 (4):1141-9. Available from: http://www.scielo.br/pdf/csc/v14n4/a15v14n4.pdf

35. Ventura M, Schramm FR. Limits and possibilities to the exercise on autonomy in therapeutic practices of physical modification and sexual identity alteration. Physis [Internet]. 2009 [cited 2019 Jan 15];19(1):65-93. Available from: http://www.scielo.br/pdf/physis/v19n1/v19n1a05.pdf

36. Ferreira BO, Pedrosa JIS, Nascimento EF. Gender diversity and access to the United Health System. Rev Bras Promoç Saúde [Internet]. 2018 [cited 2019 Jan 15];31(1):1-10. Available from: https://www.researchgate.net/ publication/323649334_Diversidade_de_genero_e_acesso_ao_Sistema_Unico_de_Saude

37. Presidência da República (BR). Decreto n 8.727, de 28 de abril de 2016. Dispõe sobre o uso do nome social e o reconhecimento da identidade de gênero de pessoas travestis e transexuais no âmbito da administração pública federal direta, autárquica e fundacional [Internet]. Diário Oficial da União 2016[cited 2019 Jan 15];28 abr. Available from: http://www.planalto.gov.br/ccivil_03/_ato2015-2018/2016/decreto/d8727.htm

38. Fredriksen-Goldsen Kl, Kim H-J, Muraco A, Mincer S. Chronically ill midlife and older lesbians, gay men, and bisexuals and their informal caregivers: the impact of the social context. Sex Res Social Policy[Internet] 2009 [cited 2019 Jan 15];6(4):52-64. Available from: https://www. ncbi.nlm.nih.gov/pmc/articles/PMC2861883/ 